\title{
Vitamin D in health and disease: Current perspectives
}

\author{
Ran Zhang ${ }^{1}$, Declan P Naughton ${ }^{2 *}$
}

\begin{abstract}
Despite the numerous reports of the association of vitamin D with a spectrum of development, disease treatment and health maintenance, vitamin D deficiency is common. Originating in part from the diet but with a key source resulting from transformation by exposure to sunshine, a great deal of the population suffers from vitamin D deficiency especially during winter months. It is linked to the treatment and pathogenesis and/or progression of several disorders including cancer, hypertension, multiple sclerosis, rheumatoid arthritis, osteoporosis, muscle weakness and diabetes. This widespread deficiency of Vitamin D merits consideration of widespread policies including increasing awareness among the public and healthcare professionals.
\end{abstract}

\section{Introduction}

Vitamin D is a group of fat-soluble prohormones which were identified after the discovery of the anti-rachitic effect of cod liver oil in the early part of the $20^{\text {th }}$ century. The vitamin found in cod liver oil was designated "D" following Vitamin A, B and C, which had been discovered earlier [1]. The two major biologically inert precursors of vitamin D are vitamin D3 (cholecalciferol) and vitamin D2 (ergocalciferol) [2,3]. Vitamin D3 is formed when 7-dehydrocholesterol in the skin is exposed to solar ultraviolet B (UVB, 290-320 nm), and then converted to previtamin D3. In a heat-dependent process, previtamin D3 is immediately converted to vitamin D. Excess UVB rays transform previtamin D3 into biologically inactive metabolites, tachysterol and lumisterol. Vitamin D2 is plant derived, produced exogenously by irradiation of ergosterol, and enters the circulation through diet [1].

Both vitamin D precursors resulting from exposure to the sunshine and the diet are converted to 25-hydroxyvitamin $\mathrm{D}[25(\mathrm{OH}) \mathrm{D}]$ (calcidiol) when they enter the liver [4]. $25(\mathrm{OH}) \mathrm{D}$ is the major circulating form of vitamin $\mathrm{D}$ and is used to determine vitamin D status. In order to be biologically active, additional hydroxylation in the kidneys is needed to form active 1,25-dihydroxyvitamin $\mathrm{D}[1,25(\mathrm{OH}) 2 \mathrm{D}]$ (calcitriol) [5]. The process of vitamin D formation is summarized in Figure 1. Humans obtain vitamin $\mathrm{D}$ through dietary intake and exposure to sunlight. Very few foods naturally contain vitamin D. Oily

\footnotetext{
* Correspondence: D.Naughton@kingston.ac.uk

${ }^{2}$ School of Life Sciences, Kingston University, Penrhyn Road, Kingston upon Thames, London KT1 2EE, UK

Full list of author information is available at the end of the article
}

fish such as salmon, mackerel, and sardines are rich in vitamin D3. Egg yolks are reported to contain vitamin D though the amounts are highly variable. Moreover, the cholesterol content of egg yolks makes it a poor source of vitamin D. Also, a small number of foods are fortified with vitamin $\mathrm{D}$ such as milk, orange juice and some bread and cereals [6,7]. A list of vitamin D content in different food sources is shown in Table 1.

Vitamin D plays an important role in maintaining an adequate level of serum calcium and phosphorus. Without vitamin D, only 10 to $15 \%$ of dietary calcium and about $60 \%$ of phosphorus is absorbed [8-10]. Therefore vitamin $\mathrm{D}$ has a great effect in forming and maintaining strong bones. It has also recently been found that vitamin $\mathrm{D}$ receptors exist in a variety of cells thus it has a biological effect on more than mineral metabolism. The aim of this report is to review key aspects relating to vitamin D deficiency, its causes, and studies on prevention of and treatment of major conditions/diseases. Thus, following a general literature review on deficiency and its causes, an overview of major meta-analyses of Vitamin D supplementation is given. This systematic approach covers metaanalyses listed in Pubmed during the past 2 decades.

\section{Vitamin D deficiency}

Vitamin $D$ deficiency and intoxication

Vitamin D deficiency occurs when people do not have an appropriate dietary intake or exposure to UVB rays. It is universally accepted that the circulating level of 25-hydroxyvitamin D should be used as an indicator of vitamin $D$ status due to its ease of measurement, long half-life in circulation (approximately 2 or 3 weeks),
C Biomed Central

() 2010 Zhang and Naughton; licensee BioMed Central Ltd. This is an Open Access article distributed under the terms of the Creative Commons Attribution License (http://creativecommons.org/licenses/by/2.0), which permits unrestricted use, distribution, and reproduction in any medium, provided the original work is properly cited. 


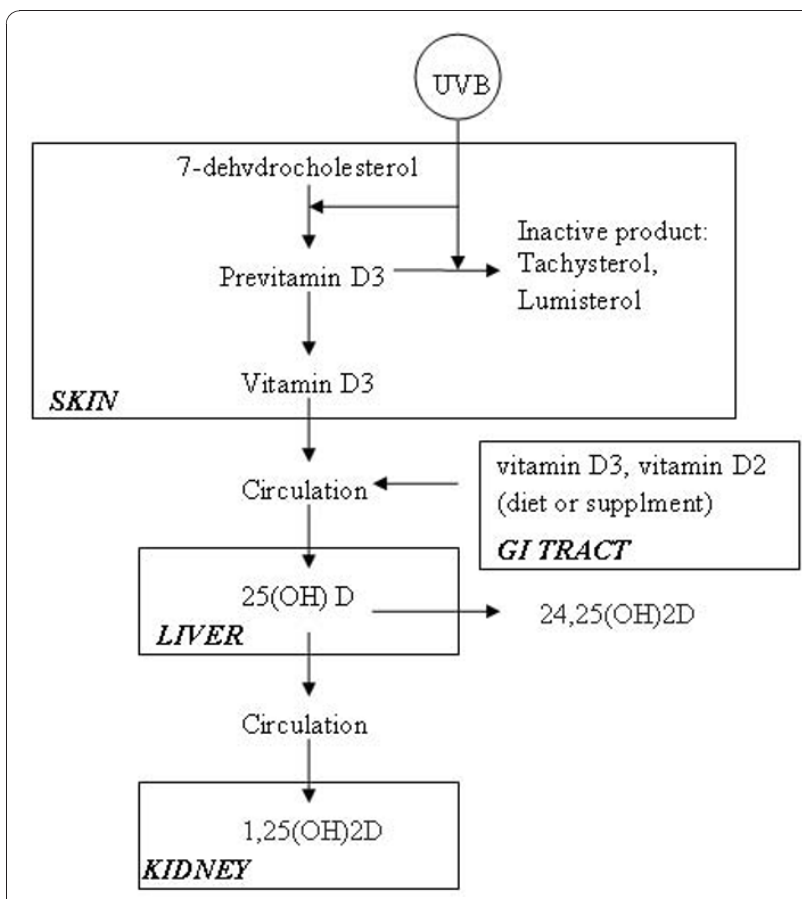

Figure 1 Sources, sites, and processing of vitamin D metabolites and the correlation of its level with clinical disease states $[1,11,12]$. Although no consensus on an optimal level of 25-hydroxyvitamin $\mathrm{D}$ has been reached, vitamin $D$ deficiency is defined by most experts as a level of less than $20 \mathrm{ng}$ per millilitre (50 nmol per litre) [13-16]. A level of 25-hydroxyvitamin D of 21 to $29 \mathrm{ng}$ per millilitre (52 to $72 \mathrm{nmol}$ per litre) is considered as an insufficiency of vitamin $\mathrm{D}$, and sufficient vitamin $\mathrm{D}$ should reach a level of $30 \mathrm{ng}$ per millilitre or greater [17].

In 1997, the Institute of Medicine of the US National Academy of Sciences recommended new adequate intakes for vitamin D as $200 \mathrm{IU}$ for children and adults up to 50 years of age, 400 IU for adults 51 to 70 years of age, and $600 \mathrm{IU}$ for adults 71 years of age or older [18]. However, a great number of studies revealed that without adequate sun exposure, children and adults require approximately 800 to 1000 IU per day [19-22].

Vitamin D intoxication is extremely rare. Studies showed that doses of more than 50,000 IU per day, which raises 25 -hydroxyvitamin $\mathrm{D}$ to more than $150 \mathrm{ng} / \mathrm{ml}$, is associated with hypercalcemia and hyperphosphatemia $[8,9,23]$. Even doses of 10,000 IU of vitamin D3 per day for up to 5 months did not cause toxicity [24]. However,

Table 1 Vitamin D3 and D2 sources and content*

\begin{tabular}{|c|c|c|}
\hline Source & & Typical Vitamin D content \\
\hline \multirow{11}{*}{ Natural source } & Salmon, fresh, wild (3.5 oz) & 600-1000 IU of vitamin D3 \\
\hline & Salmon, fresh, farmed (3.5 oz) & 100-250 IU of vitamin D3 or D2 \\
\hline & Salmon, canned (3.5 oz) & 300-600 IU of vitamin D3 \\
\hline & Sardines, canned (3.5 oz) & 300 IU of vitamin D3 \\
\hline & Mackerel, canned (3.5oz) & 250 IU of vitamin D3 \\
\hline & Tuna, canned (3.6 oz) & 230 IU of vitamin D3 \\
\hline & Cod liver oil (1 tsp) & 400-1000 IU of vitamin D3 \\
\hline & Shiitake mushrooms, fresh (3.5 oz) & 100 IU of vitamin D2 \\
\hline & Shiitake mushroom, sun-dried (3.5 oz) & $1600 \mathrm{IU}$ of vitamin D2 \\
\hline & Egg yolk & 20 IU of vitamin D3 or D2 \\
\hline & Exposure to sunlight, UVB $\left(0.5 \mathrm{MED}^{\dagger}\right)$ & 3000 IU of vitamin D3 \\
\hline \multirow{8}{*}{ Fortified foods } & Fortified butter & $50 \mathrm{IU} / 3.5 \mathrm{oz}$, usually vitamin D3 \\
\hline & Fortified milk & $100 \mathrm{IU} / 8 \mathrm{oz}$, usually vitamin D3 \\
\hline & Fortified orange juice & 100 IU/8 oz, vitamin D3 \\
\hline & Fortified yogurts & 100 IU/8 oz, usually vitamin D3 \\
\hline & Infant formulas & 100 IU/8 oz, vitamin D3 \\
\hline & Fortified margarine & 430 IU/3.5 oz, usually vitamin D3 \\
\hline & Fortified cheeses & $100 \mathrm{IU} / 3$ oz, usually vitamin D3 \\
\hline & Fortified breakfast cereals & $100 \mathrm{IU} /$ serving, usually vitamin D3 \\
\hline
\end{tabular}

* IU refers to international units, which equal $25 \mathrm{ng}$.

† About 0.5 MED of UVB radiation would be absorbed after an average of 5 to 10 minutes of exposure (depending on the time of day, season, latitude, and skin sensitivity) of the arms and legs to direct sunlight. 
patients with chronic granulomatous disorders should be cautious with the dose of vitamin D since macrophage production of 1,25-dihydroxyvitamin D causes hypercalcemia and hyperphosphatemia $[8,9,23]$.

\subsection{Causes of vitamin $D$ deficiency}

There are many causes of vitamin D deficiency. Generally, they can be divided into two groups: UVB-related deficiency and medical/physical condition-related deficiency.

\subsubsection{UVB-related deficiency}

The elderly The elderly, due to the decreased presence of skin 7-dehydrocholesterol which is the precursor for UVB mediated synthesis of vitamin D, are particularly at risk of vitamin D deficiency. Moreover, reduced mobility or institutionalization that discourages sun exposure, reduced renal production of 1,25-dihydroxyvitamin $\mathrm{D}$ as well as decreased intake of fortified foods pose great difficulties in vitamin $\mathrm{D}$ formation in body $[25,26]$.

Dark skin People with dark skin have great amounts of melanin in their epidermis. Melanin competes with 7-dehydrocholesterol for absorption of UVB photons. Therefore, people of color are less efficient in producing vitamin $\mathrm{D}$ than are whites. It is reported that a person with skin type $5 / 6$ (dark skin) requires $10-50$ times the exposure to sunlight to produce the same amount of vitamin $\mathrm{D}$ as does a white person with skin type $2 / 3$ [27].

Season, latitude, and the time of day It has been established that the ozone layer can absorb UVB radiation above $290 \mathrm{~nm}$ which is responsible for generating previtamin D3. Zenith angle, defined as the angle of the sunlight reaching the Earth's surface, decides the thickness of ozone layer which sunlight needs to penetrate. The thicker the ozone layer is, the fewer amounts of UVB photons can reach the earth, thus few previtamin D3 can be produced. Zenith angle is dependent on factors such as time of day, season of the year, and latitude. Thus those factors have great effects on vitamin D production [28,29]. For example, residents of Boston $\left(42^{\circ} \mathrm{N}\right)$, Edmonton, Canada $\left(52^{\circ} \mathrm{N}\right)$ and Bergen, Norway $\left(61^{\circ} \mathrm{N}\right)$ can not produce sufficient quantities of vitamin D in their skin for 4, 5, and 6 months, respectively [6].

Sunscreen users Sunscreens can efficiently absorb UVB radiation. This dramatically prevents the interaction of UVB with 7-dehydrocholesterol, the process of previtamin D3 generation. It has been shown that when used properly, a sunscreen with a sun protection factor of 8 reduces the production of previtamin D3 by $95 \%$, and $99 \%$ by a sun protection factor of 15 [30,31].

\subsubsection{Medical/physical condition-related deficiency}

Fat malabsorption As a fat-soluble vitamin, vitamin D requires the presence of dietary fat in the gut for absorption. Certain pathological conditions, such as
Crohn's disease, cystic fibrosis (CF), celiac disease, surgical removal of part of the stomach or intestines are associated with fat malabsorption and thus may lead to vitamin D deficiency. For example, CF patients suffer from pancreatic exocrine insufficiency. This results in malabsorption of fat-soluble vitamins, including vitamin D. CF patients, depending on the degree of exocrine insufficiency, absorb approximately $50 \%$ less vitamin D than normal [32].

Anticovulsant use Anticonvulsants, also called antiepileptic drugs, have been used to treat epileptic seizures and bipolar disorder. It is well recognized that long-term use of some antiepileptic drugs, including phenobarbital, phenytoin, and carbamazepine and the antimicrobial agent rifampicin (RIF) can result in osteomalacia [33-37]. The induction of the catabolism of 1,25-dihydroxyvitamin $\mathrm{D}$ by these drugs is thought to contribute to their deleterious side effects.

Chronic kidney disease In order to become biological active vitamin $\mathrm{D}$, kidney plays an important role in this transforming process. Chronic kidney disease such as patients with stage 4 or 5 chronic kidney disease, as well as those requiring dialysis, leads to an inability to make sufficient 1,25-dihydroxyvitamin $\mathrm{D}$ which has a direct effect in inhibiting parathyroid hormones expression [38,39]. Thus 1,25-dihydroxyvitamin D3 intake is needed to maintain calcium level in blood as well as to control parathyroid hormone levels.

Obesity It has been known for a long time that obese people are prone to be vitamin $\mathrm{D}$ deficient since they have lower 25-hydroxyvitamin D levels [40-43]. A number of studies proved that the vitamin D3 precursor 7-dehydrocholesterol levels in the skin of obese people were not significantly different from nonobese people $[26,44]$. One explanation was that the subcutaneous fat, which is known to store vitamin D, sequestered more of the cutaneous synthesized vitamin $D$, which results in less release of vitamin $D$ from the skin into the circulation in the obese subject than non-obese subject [45].

\section{Epidemiology of vitamin D inadequacy}

Several studies showed that 40 to $100 \%$ of U.S. and European elderly men and women still living in the community (not nursing homes) are deficient in vitamin D [13-15]. It has already become a largely unrecognized global epidemic. Vitamin D inadequacy can be seen in young adults as well as healthy children. For example, $48 \%$ of white preadolescent girls in a study in Maine [46] and 52\% of Hispanic and black adolescents in a study in Boston are vitamin D deficient [47]. In Europe, where very few foods are fortified with vitamin D, children and adults would appear to be at especially high risk [48-50]. A study of middle aged British adults 
showed that $60 \%$ are vitamin D insufficient, and the number rose to $90 \%$ during winter and spring [51].

\section{UVB in vitamin $D$ formation}

The resurgence of vitamin $D$ deficiency has been attributed to the lack of exposure to sunlight that has been a growing concern in the past few decades owing to associations with skin cancer. From this standpoint, along with the modern predominance for indoor living and working, it is apposite to look at photo-induced vitamin D activation. In future we may replace artificial light with a form that is more efficient at meeting our requirements for vitamin D. Ultraviolet (UV) rays are electromagnetic waves with wavelength of between 400 $\mathrm{nm}$ and $10 \mathrm{~nm}$. UV can be divided into three components according to wavelength: UVA (320-400 nm), UVB (290-320 nm), and UVC (100-290 nm). They have different skin penetration abilities, and generate different biological effects.

UVB plays a key role in vitamin D formation. It is absorbed by the epidermal layer, where the highest concentration of 7-dehydrocholesterol exists. It has been found that the optimum wavelength range for the production of vitamin D is between 295 and $300 \mathrm{~nm}$. This narrow range is sometimes referred to as D-UV [52]. As vitamin $\mathrm{D}$ is rare in the diet consumed by human beings, the major source of vitamin $\mathrm{D}$ is exposure to sunlight, particularly the UVB component $[23,53,54]$. Another advantage of UVB exposure in formation of vitamin $D$ is that UVB exposure does not result in excessive production of vitamin $\mathrm{D}$, which causes risks of intoxication. This can be explained that the previtamin D3 that is formed and the thermal isomerization product vitamin D3 that does not go into the circulation absorb UVB radiation and isomerize to several photoproducts which have little activity on calcium metabolism [55].

\section{Choice of wavelength}

As UVB exposure is not associated with vitamin D intoxication, the major concern of using UVB to boost vitamin $\mathrm{D}$ content is the erythema reaction, which is a result of cell irritation and destruction caused by ultraviolet radiation. In the UVB region, the wavelength range between 290 and $297 \mathrm{~nm}$ has the greatest erythema effect on the human body with a steep decrease above $297 \mathrm{~nm}$. Therefore UVB tubes with spectral features of minimal irradiance from 290 to 297 $\mathrm{nm}$ should always be chosen to treat vitamin D deficiency.

\section{The duration of exposure}

The duration of exposure determines the dose of UVB one receives. The product of the UVB lamp power output
$\left(\mathrm{mW} / \mathrm{cm}^{2}\right)$ and the duration of exposure is UVB radiation $\left(\mathrm{m} / \mathrm{cm}^{2}\right)$. Minimal erythema dose (MED) is defined as the minimum amount of UVB radiation that produces redness 24 hours after exposure. It is used when using UVB to treat psoriasis in order to minimize the potential for developing erythema. Therefore the radiation should not be more than one MED for safety considerations when treating vitamin D deficiency. Thus, a limit should be put on exposure time depending on power output.

It should be noted that MED varies with skin type (Table 2) and there are large variations in MED even within the same skin type [56]. According to the U.S. Food and Drug Administration and the American Academy of Dermatology, there are six skin-type categories: skin type I-VI. Generally the darker the skin, the harder it is for the skin to burn, thus the higher the value of MED which results in a longer exposure duration to achieve a certain value of MED.

\subsection{Vitamin D production}

It has been reported that exposure of $6-10 \%$ of the body surface to 1 MED is equivalent to ingesting about 600 $1000 \mathrm{IU}$ of vitamin D [57]. In general, when using UVB radiation in vitamin $\mathrm{D}$ formation, the factors influencing vitamin $\mathrm{D}$ production can be summarized as: the UVB radiation, the exposure duration and body exposure area. The stronger the radiation is (under certain limits), the longer the exposure duration is (under certain limits), the larger the body exposure area is, the more vitamins can be produced.

A number of studies have been conducted to improve vitamin D content using UVB rays [58-61]. 45 female psychogeriatric patients in nursing homes received $1 / 2$ MED UVB irradiation, three times per week, for 12 weeks. Results showed that 1,25-dihydroxyvitamin D levels increased significantly from $30 \mathrm{nmol} / \mathrm{l}$ to $60 \mathrm{nmol} / \mathrm{l}$ on average [62]. Another study using UV light to treat vitamin $\mathrm{D}$ deficiency resulted from malabsorption indicated that 25 -hydroxyvitamin levels increased by $28 \%$ at the end of 8 weeks [63].

\subsection{Contraindications}

UVB irradiation does not appear to suit some individuals who develop headache, nausea and possibly vomiting and rise of temperature after exposure. Also people with sensitive skin may react strongly to UV rays, thus are unsuitable for UV treatment [64].

Certain drugs could make individuals become more susceptible than normal to the effects of UV radiation, examples being gold, the sulphonamides, insulin, thyroid extract, and quinine. Therefore UVB should not be used in conjunction with these drugs. An area which has recently been subjected to doses to X-rays is not suitable for UVB treatment since it may cause carcinoma of the skin. UV may also cause the aggravation of certain diseases such as pulmonary tuberculosis, acute eczema 
Table 2 Skin type categories from Food and Drug Administration (FDA) and the American Academy of Dermatology

\begin{tabular}{lll}
\hline Skin types & Sun history & Example \\
\hline II & Always burns easily, never tans, extremely sensitive skin & Red-headed, freckled, Celtic, Irish-Scots \\
\hline III & Always burns easily, tans minimally, very sensitive skin & Fair-skinned, fair-haired, blue-eyed Caucasians \\
\hline $\mathrm{IV}$ & Sometimes burns, tans gradually to light brown, sun-sensitive skin & Average-skinned Caucasians, light-skinned Asians \\
\hline $\mathrm{V}$ & Burns minimally, always tans to moderate brown, minimally sun-sensitive & Mediterranean-type Caucasians \\
\hline $\mathrm{VI}$ & Rarely burns, tans well, sun-insensitive skin & Middle Easterners, some Hispanics, some African-Americans \\
\hline
\end{tabular}

or dermatitis [64]. Thus it is not appropriate to apply UVB in these conditions.

\subsection{Vitamin $D$ intake in different conditions}

The association of low status of vitamin D with several diseases has been long established. Increasing vitamin D levels through oral supplementation or sunlight exposure is vital in the management of these conditions. Also, vitamin D has been used to treat some minor abnormalities, such as tooth loss and depressed moods, in order to maintain a healthy lifestyle. Moreover, research during the past two decades has highlighted the important role of vitamin $\mathrm{D}$ in reducing the risks of a series of conditions including cancer, multiple sclerosis, hypertension, to name a few. In this section, the utility of vitamin $\mathrm{D}$ for different purposes such as disease management, prevention, and improvement of quality of life will be discussed.

\section{Disease management}

A large number of trials have been conducted over the past two decades into the effects of vitamin D on disease management and prevention. The efficacies of vitamin $\mathrm{D}$, as demonstrated by the meta-analyses reported in this period, are largely unconvincing apart from in relation to falls and fractures in the elderly. These meta-analyses, summarized in Table 3 do not show a substantial role for vitamin D either through prevention or treatment of many conditions for which it is associated. It should be noted that many of the metaanalysis relied on disparate studies which introduces significant questions regarding the results. Despite this overview, and in a somewhat unorthodox approach some key studies will be discussed below that may lead to more focused and appropriate trials.

\section{Osteoporosis}

Approximately 33\% of women aged between 60 to 70 and $66 \%$ of those over 80 have osteoporosis [13]. The link between vitamin D deficiency and osteoporosis has been well established especially in the elderly. Vitamin $\mathrm{D}$ deficiency is associated with the marked suppression in intestinal $\mathrm{Ca}$ absorption and the impairment of $\mathrm{Ca}$ balance, which results in low bone mineral content and density. Reduced bone mineral density (BMD) increases the risk of fractures, which significantly contributes to morbidity and mortality of older persons $[65,66]$. Hip fracture is expected to be more prevalent worldwide with the increase in aging of the population, and the consequences are severe: $50 \%$ of older persons have permanent functional disabilities, $15 \%$ to $25 \%$ require longterm nursing home care, and $10 \%$ to $20 \%$ die within 1 year.

The efficacy of vitamin D as a prevention of fracture has been demonstrated by a number of studies. Trials using 700 to $800 \mathrm{IU} / \mathrm{d}$ oral vitamin D with or without calcium supplementation found a significant $26 \%$ reduction in risk of sustaining a hip fracture and a significant $23 \%$ reduction in risk of sustaining any non-vertebral fracture versus calcium or placebo [67]. Also, a 3-year French study of 3270 elderly women (mean age 84 years) living in care home, where vitamin D deficiency is prevalent, indicates that calcium (1200 mg daily) and vitamin D (800 IU daily) can reduce the probability of hip and all non-vertebral fractures by $43 \%$ and $32 \%$, respectively, compared with placebo $[68,69]$. Conversely, a Dutch study of 2578 healthy elderly women treated with a high calcium intake, daily supplementation with vitamin D $400 \mathrm{IU}$ over 3.5 years showed no effect on the risk of hip fracture [70]. Therefore, whether $400 \mathrm{IU}$ vitamin D is enough to prevent fracture in healthy elderly subjects with normal BMD needs further investigation.

\section{Muscle weakness}

Muscle weakness is also a prominent feature of vitamin D deficiency. Patients with nonspecific muscle weakness, muscle aches and pains have also been found with vitamin D inadequacy [71,72]. Impaired muscle function is known to cause an increased number of falls which can lead to hip fractures. The incidence of falls go up substantially in those older than 70 years of age, and over $90 \%$ of hip factures resulted from a fall. It has been established that skeletal muscle tissue contains vitamin $\mathrm{D}$ receptor and may require vitamin $\mathrm{D}$ to realize maximum function $[23,73]$. 
Table 3 Systematic reviews on Vitamin D for prevention or treatment (in chronological order)

\begin{tabular}{|c|c|c|c|c|c|}
\hline Area & $\begin{array}{l}\text { Number } \\
\text { of studies }\end{array}$ & Type & Doses & Conclusion & Reference \\
\hline Cardiovascular events & 17 & Prospective & $\sim 1000 \mathrm{IU}$ & S not SS & 162 \\
\hline Cardiometabolic outcomes & 31 & Observ/Trial & Range & No effect & 163 \\
\hline Fracture prevention & 7 & Randomised & $\begin{array}{l}10-20 \mathrm{mcg} \\
+\mathrm{Ca}\end{array}$ & $\begin{array}{l}\text { No effect } \\
\text { Reduced risk }\end{array}$ & $\begin{array}{l}164 \\
164\end{array}$ \\
\hline Physical performance & $\begin{array}{l}8 \\
8\end{array}$ & $\begin{array}{l}\text { Observational } \\
\text { Intervention }\end{array}$ & $\begin{array}{l}- \\
-\end{array}$ & $\begin{array}{l}\text { Positive (5/8) } \\
\text { Mixed }\end{array}$ & $\begin{array}{l}165 \\
165\end{array}$ \\
\hline $\begin{array}{l}\text { Kidney disease } \\
\text { (-dialysis) }\end{array}$ & 16 & $\mathrm{RCT}$ & - & Uncertain & 166 \\
\hline Kidney disease (+dialysis) & 60 & $\mathrm{RCT}$ & - & Uncertain & 167 \\
\hline Cystic fibrosis & 3 & (q) $\mathrm{RCT}$ & 800-1600IU & No effect & 168 \\
\hline Risk of falling & 8 & $\mathrm{RCT}$ & $\begin{array}{l}\text { 700-1000IU } \\
\text { 200-600IU }\end{array}$ & $\begin{array}{l}\text { Reduced risk } \\
\text { No effect }\end{array}$ & $\begin{array}{l}169 \\
169\end{array}$ \\
\hline Hypertension & 11 & RCT & - & $S-S S$ & 170 \\
\hline Risk of falling & $111^{*}$ & RT or interv. & - & No effect & 171 \\
\hline Fracture prevention & 45 & (q) RCT & $\begin{array}{l}- \\
+\mathrm{Ca}\end{array}$ & $\begin{array}{l}\text { No effect } \\
\text { S not SS }\end{array}$ & $\begin{array}{l}172 \\
172 \\
\end{array}$ \\
\hline Risk of Type 1 diabetes & 5 & Observational & - & Uncertain & 136 \\
\hline Parathyroid hormone & 52 & Intervention & - & Decrease & 173 \\
\hline Mortality & 18 & RCT & $2300-2000 \mid \mathrm{IU}$ & Uncertain & 174 \\
\hline Risk of fall/fracture & 9 & - & - & Decrease (trend) & 175 \\
\hline Risk of fracture & 12 & $\mathrm{RCT}$ & $\begin{array}{l}700-800 I U \\
400 I U\end{array}$ & $\begin{array}{l}\text { Decrease (trend) } \\
\text { No effect }\end{array}$ & $\begin{array}{l}176 \\
176\end{array}$ \\
\hline Risk of fall & 10 & $\mathrm{RCT}$ & - & Decrease & 177 \\
\hline Bone density Fracture & $\begin{array}{l}17 \\
17\end{array}$ & $\begin{array}{l}\mathrm{RCT} \\
\mathrm{RCT}\end{array}$ & $\begin{array}{l}- \\
-\end{array}$ & $\begin{array}{l}\text { Uncertain } \\
\text { Reduction }\end{array}$ & 178 \\
\hline
\end{tabular}

S not SS: Small effect - not statistically significant (sub-groups are discounted); RCT: Randomised controlled trial $\left\{(q)\right.$ - quasi\}; ${ }^{*}$ Multiple factor study.

It has been reported that increased vitamin D levels can improve muscle performance, and thus reduce the incidence of fall. In a 5-month randomized controlled trial, elderly people in a nursing home received $800 \mathrm{IU}$ of vitamin D2 plus calcium daily, exhibited a $72 \%$ reduction in the risk of falls as compared with the placebo group [74]. Long-term intake of $700 \mathrm{IU}$ vitamin D plus $500 \mathrm{mg}$ of calcium in 246 community-dwelling older women also showed a beneficial reduction falls: the odds of falling declined by $46 \%$ compared with the placebo group [74]. However, the results from one trial suggested that $400 \mathrm{IU}$ vitamin per day may not be clinical effective in preventing falls in the elderly [75].

\section{Hypertension}

Millions of people are affected by hypertension worldwide. Growing evidence in recent years suggests that vitamin $\mathrm{D}$ has an important association with blood pressure. Animal experiments implicate 1,25dihydroxyvitamin $\mathrm{D}$ in inhibiting renin expression in the juxtaglomerular apparatus and blocks proliferation of vascular smooth muscle cells (VSMC), which could influence systemic blood pressure [76-79]. Studies showed that Afro-Americans have a significantly higher prevalence of diastolic hypertension [80] and have lower 25-hydroxyvitamin D levels [81] compared with white Americans.

Reduced blood pressure has been found in people taking oral supplementation of vitamin D. In humans, skin exposure to UVB, which is the major source of vitamin $\mathrm{D}$ formation, has been linked with lower blood pressure [82-84]. An 8-week single intervention study of 148 vitamin $\mathrm{D}$ deficient elderly women demonstrated a $9 \%$ decrease in systolic blood pressure with supplemental vitamin D (800 IU) plus calcium (1200 mg) compared with calcium alone [85]. In another study, patients with hypertension were exposed to UVB radiation three times a week for 3 months. Results showed that 25hydroxyvitamin D levels increased by approximately $180 \%$, and both systolic and diastolic blood pressure reduced by $6 \mathrm{~mm} \mathrm{Hg}$ [84]. In contrast, a large prospective study of men and women found no association between intake of vitamin $\mathrm{D}$ from diet and supplements and hypertension incidents [86]. This difference may be attributed to the fact that the large observational study included subjects from the general public while other 
studies recruited hypertension patients. Thus the original vitamin $\mathrm{D}$ levels could have certain impacts on treatment effect.

\section{Multiple sclerosis}

Multiple sclerosis (MS) is an autoimmune disease in which the body's immune system attacks myelin, a key substance that serves as a nerve insulator and helps in the transmission of nerve signals. It has been long recognised that MS is more common in temperate climates than the tropics $[87,88]$, and annual and winter hours of sunlight have been proved to have the strongest negative correlation with the prevalence of MS $[89,90]$. One explanation is that the increase of vitamin $D$ results from sunlight exerting a protective effect [91-93]. Studies also found that individuals with MS tend to have insufficient vitamin D levels [71,94-97].

However, only a few reports are available on the use of vitamin $\mathrm{D}$ in treating MS patients. One study (6 months) of the cytokine profile in MS patients with vitamin D (1000 IU/day) and calcium (800 mg/day) showed that 25-hydroxyvitamin D significantly increased from $42.5 \pm$ 15 to $70 \pm 20 \mathrm{nmol} / \mathrm{l}$. Also vitamin D supplementation significantly increase serum transforming growth factor (TGF)- $\beta 1$, which has been shown to be an important anti-inflammatory cytokine in animal models of MS [98]. The increased TGF- $\beta 1$ suggests that vitamin D supplementation could potentially improve the symptoms of MS patients. Nonetheless, more studies are needed to establish vitamin D's efficacy in alleviating MS.

Apart from improving MS patients' health conditions, vitamin $\mathrm{D}$ has also been shown to have effects in preventing MS. One study revealed that women who used supplemental vitamin D (> $400 \mathrm{IU} /$ day) had a 40\% lower risk of MS than women who did not use vitamin D [99]. Another report among 7 million US military personnel reported that risk of MS decreased with increasing 25-hydroxyvitamin D which provided an evidence of vitamin D's protective role in MS developing [100].

\section{Malabsorption}

As explained above, certain conditions cause malabsorption, which results in vitamin D deficiency. Low BMD can be frequently found in these conditions. Thus vitamin D supplementation is required to boost vitamin D sera levels. For example, Cystic fibrosis (CF) patients have inefficient vitamin $\mathrm{D}$ absorption due to pancreatic exocrine insufficiency. It is reported that $95 \%$ of a treated cohort of CF patients required $1800 \mathrm{IU}(45 \mu \mathrm{g} / \mathrm{d}$ or $0.13 \mathrm{mmol}$ ) of ergocalciferol (vitamin D2) daily to achieve a 25OHD concentration above $25 \mathrm{ng} / \mathrm{ml}$ [101]. Vitamin D deficiency is prevalent in Crohn's Disease (CD). CD is an inflammatory bowel disease which often leads to osteopenia and osteoporosis due to malabsorption of vitamin D. One study conducted on 154 CD patients for 76 days showed that daily calcium $(500 \mathrm{mg}$ ) and vitamin D (400 IU) supplementation was associated with an increase in bone mineral density [102].

\section{Vitamin D associations with disease prevention Rickets}

With the re-arrival of widespread vitamin D deficiency, the re-emergence of rickets, a scourge from the ninetieth century was inevitable. In a recent review, the deficiency rates found in countries where extreme sunlight levels are readily available but people are covered or avoid sunlight and do not have access to vitamin D-fortified foods [23]. Insufficient levels of vitamin D in breastfeeding mothers can, often unknowingly, lead to deficiencies in children. It is suggested that a supplement level of $400 \mathrm{IU} / \mathrm{d}$ for infants as practiced in Canada is optimal [23].

\section{Cancer}

The first study indicating that sunlight exposure may lower the risk of cancer was first made almost seven decades ago [103]. Garland and Garland were the first to propose that vitamin $\mathrm{D}$ deficiency may contribute to a higher risk of colon cancer mortality since vitamin D is formed in the skin through solar UVB radiation. More recently, the discovery of increased risks of certain types of cancer in those who are vitamin D deficient, suggests that vitamin $\mathrm{D}$ deficiency may account for thousands of premature deaths from colon [104], breast $[105,106]$, ovarian [107], and prostate cancer [108] every year.

Vitamin D is one of the most potent hormones for regulating cell growth. It was discovered that many cell types contain vitamin $\mathrm{D}$ receptors. These receptors can be activated by $1,25(\mathrm{OH}) 2 \mathrm{D}$, and induce differentiation into normally functioning cells, and inhibit proliferation, invasiveness, angiogenesis, and metastatic potential. In tumor models such as cancers of the lung [109-111], colon [112], kidney [113], breast [114], and prostate [115], vitamin D played a role in activity against metastasis [116-120].

The protective relationship between sufficient vitamin D status and lower risk of cancer has been found in many studies. It has been reported that breast and colorectal cancer can be reduced by $50 \%$ with the concentration of 25-hydroxyvitamin D being $>32 \mathrm{ng} / \mathrm{mL}[121,122]$. A similar study of colorectal cancer found that a level of $34 \mathrm{ng} / \mathrm{mL} 25$-hydroxyvitamin D can reduce the incidence by half, and $46 \mathrm{ng} / \mathrm{mL}$ can decrease it by two thirds [123]. A 4-year trial on postmenopausal women showed that $1100 \mathrm{IU} /$ day vitamin D plus $1400-1500 \mathrm{mg} /$ day calcium can substantially reduces all-cancer risk [121]. 


\section{Rheumatoid Arthritis (RA)}

RA is an autoimmune disorder of unknown etiology in which both genetic and nongenetic factors contribute to disease susceptibility [124]. The immunomodulatory effect of Vitamin D has received increasing attention in recent years. Studies showed that when confronted by an inappropriate and overly exuberant immune response, vitamin $\mathrm{D}$ may act in a paracrine manner to decrease $T$ cell responsiveness through the inhibition of cellular proliferation and reduction in lymphokine production [125-128]. Therefore vitamin D has a beneficial effect as an immunosuppressant.

Vitamin D has shown its ability to suppress the development of autoimmunity in animal experiments. For example, murine models of human RA demonstrated that when treated with active vitamin $\mathrm{D}$, both the incidence and severity of the disease in mice decreased [129]. However the association of vitamin D intake and RA incidence in humans has not been well studied. One study of 30,000 women aged 55 to 69 over 11 years observed an inverse association between greater intake of vitamin D and RA risk [130]. Interestingly, vitamin D from supplements showed a stronger influence in RA development than did dietary vitamin D. However, further studies are needed to establish the effect of vitamin $\mathrm{D}$ in the prevention of RA.

\section{Diabetes}

A diabetes epidemic has emerged during the $20^{\text {th }}$ century. The prevalence of diabetes for all age groups was estimated to be $2.8 \%$ in 2000 , and this number will increase to $4.4 \%$ by 2030 [131]. It has been reported as early as the $1980 \mathrm{~s}$ that vitamin D deficiency inhibits pancreatic secretion and turnover of insulin, resulting in impaired glucose tolerance $[132,133]$. An association was found between low UVB irradiance, indicating a low level of vitamin $\mathrm{D}$, and high incidence of type 1 diabetes, whereas the incidence rate approached zero in regions with high UVB irradiance [134-137].

A study of 83,779 women with no history of diabetes over 2-4 years showed that a combined daily intake of $>1200 \mathrm{mg}$ calcium and $>800$ IU vitamin D was associated with $33 \%$ lower risk of type 2 diabetes as compared with a daily intake of less than $600 \mathrm{mg}$ of calcium and less than $400 \mathrm{IU}$ of vitamin D [138]. Another study on 10,366 children in Finland over 31 years indicated that $2000 \mathrm{IU}$ of vitamin D per day during their first year of life can reduce the risk of type 1 diabetes by approximately $80 \%$ [139].

\section{Tuberculosis (TB)}

TB is a major global problem and responsible for 2 million deaths a year. It is estimated that one-third of the global population has latent TB infection [140], which poses great potential risks of reactivation in the future. In fact, before antibiotics came in to use, high doses of vitamin D were widely used to treat active TB [141]. Cross-sectional studies showed that patients with $\mathrm{TB}$ have lower 25(OH)D levels in comparison with control subjects $[142,143]$. Recently, it was found that low vitamin D status resulting from a vegetarian diet is an independent risk factor for active TB in South Asians [144].

Until now studies evaluating the effect of vitamin D on the body's immunity to mycobacteria, the family of bacteria that cause TB, are scanty. One study measuring 192 healthy adult TB contacts' showed that a single oral dose of $2.5 \mathrm{mg}$ vitamin D significantly enhanced participants' whole blood ability to restrict functional whole blood (BCG-lux) luminescence in vitro [145]. It concluded that vitamin D enhances TB contacts' immunity to mycobacteria. However, the effect of vitamin D supplementation on TB incidence rates among deficient population with high rates of latent TB infection should be investigated to determine vitamin D's prevention effect in TB.

\section{Health maintenance and Vitamin D}

Besides treating and preventing a range of disease, vitamin D has also been applied in managing minor abnormalities so as to improve quality of life.

Periodontal disease is a common chronic inflammatory disease characterized by loss of periodontal attachment. It is the leading cause of tooth loss [146-150] which has a great impact in nutrient intake the quality of life [151-153]. Several epidemiologic studies revealed that there is link between osteoporosis and tooth loss, which indicate that the cause of osteoporosis could also contribute to periodontal disease. A 3-year study showed that supplementation with vitamin D (700 IU/d) plus calcium $(500 \mathrm{mg} / \mathrm{d})$ significantly reduced tooth loss in older people [154].

Mood changes with season, a common phenomenon is that anxiety and depression increase during winter months. An extreme case of this seasonality is a clinical syndrome called seasonal affective disorder (SAD), also known as winter depression. One explanation is the changing level of vitamin D3 during winter. One study, including 44 healthy subjects during winter, investigated the efficacy of vitamin D3 in enhancing mood. Results on a self-report showed that vitamin D3 significantly enhance positive affect [155].

Vitamin D has also been found to play an important role in brain development and function [156-159]. The study pointed out the wide distribution of vitamin $\mathrm{D}$ receptors throughout the brain. It showed that vitamin D has the ability to affect proteins which are known to be directly involved in learning and memory, motor control, and possibly even maternal and social behavior [160]. Maintaining 
vitamin D sufficiency in utero and during early life ensures the normal receptor transcriptional activity in the brain. This may be vital for brain development and also the maintenance of mental function later in life [161].

As shown in Table 3 the postulated efficacies of vitamin $\mathrm{D}$, as demonstrated by the meta-analyses reported are largely unconvincing for most diseases/conditions apart from in relation to falls and fractures in the elderly [162-178]. Despite considerable efforts to explore the benefits of vitamin $D$, little convincing evidence has been presented in the form of meta-analyses in relation to the cardiovascular system, kidney function, Cystic fibrosis, diabetes, and mortality. The meta-analyses relied on disparate studies with varied approaches to measuring vitamin $\mathrm{D}$ analogues which may introduce significant questions regarding the results. It is suggested that further standardization should be introduced regarding which forms of vitamin D are measured and how they are measured.

\section{Conclusions}

Vitamin D inadequacy is a global problem. Approximately $36 \%$ of otherwise healthy young adults and up to $57 \%$ of general medicine inpatients in the United States suffer from vitamin D inadequacy. These figures are even higher in Europe [71].

In the past, vitamin $\mathrm{D}$ intake was associated with the prevention of rickets in children whereas its effect in other areas has received little attention. In recent years, vitamin $\mathrm{D}$ deficiency has also been linked with the pathogenesis and/or progression of several disorders, including cancer, hypertension, multiple sclerosis, diabetes although the evidence for the associations of vitamin D with these conditions is generally weaker than it is for bone-related disease.

Although recommendations of daily vitamin D intake have been provided, higher levels are required in order to have real preventive or treatment effects as numerous studies have proved. UVB radiation plays an alternative in improving vitamin D content other than oral supplementation. Its advantage is that it will not cause vitamin $\mathrm{D}$ intoxication since excessive vitamin $\mathrm{D}$ will be broken down by UVB. However, a number of factors of the UVB such as wavelength, duration of exposure are needed to be carefully controlled so as to avoid erythema.

Despite the close link of vitamin D with human health, vitamin D inadequacy is not widely recognized as a problem by physicians and patients. Greater awareness of this problem is required among researchers, clinician, and patients of the high prevalence of vitamin $\mathrm{D}$ inadequacy.

\section{Acknowledgements}

The work was funded by the London Development Agency through a London Innovation Placements Programme located at Allergy Matters Ltd.

\section{Author details}

${ }^{1}$ AllergyMatters Ltd, 5a Kingston House Estate, Portsmouth Rd., Long Ditton Surrey, England KT6 5QG, UK. ${ }^{2}$ School of Life Sciences, Kingston University, Penrhyn Road, Kingston upon Thames, London KT1 2EE, UK.

\section{Authors' contributions}

RZ conducted the initial substantial literature search, prepared the preliminary document and assisted with final version. DPN initiated the study, directed and augmented the literature search, and completed the final document. All authors have read and approved the final manuscript.

\section{Competing interests}

RZ was funded by a London Innovation Placements Programme sponsored by Allergy Matters Ltd (http://www.allergymatters.com).

Received: 26 August 2009 Accepted: 8 December 2010 Published: 8 December 2010

\section{References}

1. Wolpowitz D, Gilchrest BA: The vitamin D questions: how much do you need and how should you get it? J Am Acad Dermatol 2006, 54:301-317.

2. Holick MF: The use and interpretation of assays for vitamin D and its metabolites. J Nutr 1990, 120(Suppl):1464-1469.

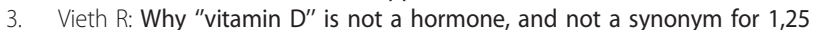
dihydroxy-vitamin D, its analogs or deltanoids. J Steroid Biochem Mol Biol 2004, 89-90:571-573.

4. Holick MF: The role of vitamin D for bone health and fracture prevention. Curr Osteoporos Rep 2006, 4:96-102.

5. Malone RW, Kessenich C: Vitamin D deficiency: implications across the lifespan, the journal for nurse practitioners. J Nurse Practitioners 2008, 6:448-454.

6. Holick MF: Vitamin D: importance in the prevention of cancers, type 1 diabetes, heart disease, and osteoporosis. Am J Clin Nutr 2004, 79:362-371.

7. Tangpricha V, Koutkia P, Rieke SM, Chen TC, Perez AA, Holick MF: Fortification of orange juice with vitamin D: a novel approach to enhance vitamin D nutritional health. Am J Clin Nutr 2003, 77:1478-1483.

8. Holick MF, Garabedian M: Vitamin D: photobiology, metabolism, mechanism of action, and clinical applications. In Primer on the metabolic bone diseases and disorders of mineral metabolism. 6 edition. Edited by: Favus MJ. Washington, DC: American Society for Bone and Mineral Research; 2006:129-137.

9. Bouillon R: Vitamin D: from photosynthesis, metabolism, and action to clinical applications. In Endocrinology. Edited by: DeGroot $L$, Jameson JL. Philadelphia: W.B. Saunders; 2001:1009-1028.

10. DeLuca HF: Overview of general physiologic features and functions of vitamin D. Am J Clin Nutr 2004, 80:1689S-1696S.

11. Adams JS, Clemens TL, Parrish JA, Holick MF: Vitamin-D synthesis and metabolism after ultraviolet irradiation of normal and vitamin-Ddeficient subjects. N Engl J Med 1982, 306:722-725.

12. Reichel $H$, Koeffler HP, Norman AW: The role of the vitamin D endocrine system in health and disease. N Engl J Med 1989, 320:980-991.

13. Michael F: Vitamin D Deficiency. N Engl J Med 2007, 357:266-281.

14. Holick MF, Siris ES, Binkley N, Beard MK, Khan A, Katzer JT, Petruschke RA, Chen E, de Papp AE: Prevalence of vitamin D inadequacy among postmenopausal North American women receiving osteoporosis therapy. J Clin Endocrinol Metab 2005, 90:3215-3224.

15. Lips P, Hosking D, Lippuner K, Norquist JM, Wehren L, Maalouf G, Ragi-Eis S, Chandler J: The prevalence of vitamin $D$ inadequacy amongst women with osteoporosis: an international epidemiological investigation. $J$ Intern Med 2006, 260:245-254

16. Thomas KK, Lloyd-Jones DM, Thadhani RI, Shaw AC, Deraska DJ, Kitch BT, Vamvakas EC, Dick IM, Prince RL, Finkelstein JS: Hypovitaminosis D in medical inpatients. N Engl J Med 1998, 338:777-783. 
17. Dawson-Hughes B, Heaney RP, Holick MF, Lips P, Meunier PJ, Vieth R: Estimates of optimal vitamin D status. Osteoporos Int 2005, 16:713-716.

18. Standing Committee on the Scientific Evaluation of Dietary Reference Intakes Food and Nutrition Board, Institute of Medicine. Vitamin D. Dietary reference intakes for calcium, phosphorus, magnesium, vitamin D, and fluoride Washington, DC: National Academy Press; 1999, 250-287.

19. Glerup H, Mikkelsen K, Poulsen L, Hass E, Overbeck S, Thomsen J, Charles P, Eriksen EF: Commonly recommended daily intake of vitamin $D$ is not sufficient if sunlight exposure is limited. J Intern Med 2000, 247:260-268.

20. Boonen S, Bischoff-Ferrari HA, Cooper C, Lips P, Ljunggren O, Meunier PJ, Reginster JY: Addressing the musculoskeletal components of fracture risk with calcium and vitamin D: a review of the evidence. Calcif Tissue Int 2006, 78:257-270.

21. Larsen ER, Mosekilde L, Foldspang A: Vitamin D and calcium supplementation prevents osteoporotic fractures in elderly community dwelling residents: a pragmatic population-based 3-year intervention study. J Bone Miner Res 2004, 19:370-378.

22. Staud R: Vitamin D: more than just affecting calcium and bone. Curr Rheumatol Rep 2005, 7:356-364.

23. Holick MF: Resurrection of vitamin D deficiency and rickets. J Clin Invest 2006, 116:2062-2072.

24. Vieth $\mathrm{R}$ : Why the optimal requirement for vitamin D3 is probably much higher than what is officially recommended for adults. J Steroid Biochem Mol Biol 2004, 89-90:575-579.

25. Bell NH: Vitamin D metabolism, aging, and bone loss. J Clin Endocrinol Metab 1995, 80:1051.

26. Need AG, Morris HA, Horowitz M, Nordin C: Effects of skin thickness, age, body fat, and sunlight on serum 25-hydroxyvitamin D. Am J Clin Nutr 1993, 58:882-885.

27. Clemens TL, Henderson SL, Adams JS, Holick MF: Increased skin pigment reduces the capacity of skin to synthesis vitamin D3. Lancet 1982, 1:74-76.

28. Webb AR, Kline L, Holick MF: Influence of season and latitude on the cutaneous synthesis of vitaminD3: exposure to winter sunlight in Boston and Edmonton will not promote vitamin D3 synthesis in human skin. J Clin Endocrinol Metab 1988, 67:373-378.

29. Lu Z, Chen TC, Kline L, Markestad T, Pettifor J, Ladizesky M, Mautalen C, Holick MF: Photosynthesis of previtamin D3 in cities around the world. In Biologic effects of light. Edited by: Holick MF, Kligman A. Symposium proceedings, October 13-15:1991. Berlin: Walter De Gruyter 1992:48-51.

30. Matsuoka LY, Ide L, Wortsman J, MacLaughlin J, Holick MF: Sunscreens suppress cutaneous vitamin D3 synthesis. J Clin Endocrinol Metab 1987, 64:1165-1168

31. Holick MF: McCollum Award Lecture, 1994: Vitamin D-new horizons for the 21st century. Am J Clin Nutr 1994, 60:619-630.

32. Lo CW, Paris PW, Clemens TL, Nolan J, Holick MF: Vitamin D absorption in healthy subjects and in patients with intestinal malabsorption syndromes. Am J Clin Nutr 1985, 42:644-649.

33. Pack AM, Morrell MJ: Epilepsy and bone health in adults. Epilepsy Behav 2004, 5(Suppl. 2):S24-S29.

34. Andress DL, Ozuna J, Tirschwell D, Grande L, Johnson M, Jacobson AF, Spain W: Antiepileptic drug induced bone loss in young male patients who have seizures. Arch Neurol 2002, 59:781-786.

35. Burt R, Freston JW, Tolman KG: The influence of phenobarbital on biotransformation of 25-hydroxycholecalciferol. J Clin Pharmacol 1976, 16:393-398.

36. Shah SC, Sharma RK, Chitle AR: Rifampicin induced osteomalacia. Tubercle 1981, 62:207-209.

37. Karaaslan Y, Haznedaroglu S, Ozturk M: Osteomalacia associated with carbamazepine/valproate. Ann Pharmacother 2000, 34:264-265.

38. Dusso AS, Sato T, Arcidiacono MV, Alvarez-Hernandez D, Yang J, GonzalezSuarez I, Tominaga Y, Slatopolsky E: Pathogenic mechanisms for parathyroid hyperplasia. Kidney Int Suppl 2006, 102:S8-S11.

39. Correa P, Segersten U, Hellman P, Akerstrom G, Westin G: Increased 25hydroxyvitamin D3 1a-hydroxylase and reduced 25-hydroxyvitamin D3 24-hydroxylase expression in parathyroid tumors - new prospects for treatment of hyperparathyroidism with vitamin D. J Clin Endocrinol Metab 2002, 87:5826-5829.

40. Liel Y, Ulmer E, Shary J, Hollis BW, Bell NH: Low circulating vitamin D in obesity. Calcif Tissue Int 1988, 43:199-201.
41. Compston JE, Vedi S, Ledger JE, Webb A, Gazet JC, Pilkington TRE: Vitamin D status and bone histomorphometry in gross obesity. Am J Clin Nutr 1981, 34:2359-2363.

42. Hey $\mathrm{H}$, Stockholm KH, Lund BJ, Sorensen OH: Vitamin D deficiency in obese patients and changes in circulating vitamin $D$ metabolites following jejunoileal bypass. Int J Obes 1982, 6:473-479.

43. Hyldstrup L, Andersen T, McNair P, Breum L, Transbol I: Bone metabolism in obesity: changes related to severe overweight and dietary weight reduction. Acta Endocrinol 1993, 129:393-398.

44. MacLaughlin J, Holick MF: Aging decreases the capacity of human skin to produce vitamin D3. J Clin Invest 1985, 76:1536-1538.

45. Wortsman J, Matsuoka LY, Chen TC, Lu Z, Holick MF: Decreased bioavailability of vitamin D in obesity. Am J Clin Nutr 2000, 72:690-693.

46. Sullivan SS, Rosen CJ, Halteman WA, Chen TC, Holick MF: Adolescent girls in Maine at risk for vitamin D insufficiency. J Am Diet Assoc 2005, 105:971-974.

47. Gordon CM, DePeter KC, Feldman HA, Grace E, Emans SJ: Prevalence of vitamin D deficiency among healthy adolescents. Arch Pediatr AdolesC Med 2004, 158:531-537.

48. Lips P: Vitamin D deficiency and secondary hyperparathyroidism in the elderly: consequences for bone loss and fractures and therapeutic implications. Endocr Rev 2001, 22:477-501.

49. Bakhtiyarova S, Lesnyak O, Kyznesova N, Blankenstein MA, Lips P: Vitamin D status among patients with hip fracture and elderly control subjects in Yekaterinburg, Russia. Osteoporos Int 2006, 17:441-446.

50. McKenna MJ: Differences in vitamin D status between countries in young adults and the elderly. Am J Med 1992, 93:69-77.

51. Hypponen and Power: Hypovitaminosis D in British adults at age 45y: nationwide cohort study on dietary and lifestyle predictors. Am J Clin Nutr 2007, 85:860-868.

52. MacLaughlin JA, Anderson RR, Holick MF: Spectral character of sunlight modulates photosynthesis of previtamin D3 and its photoisomers in human skin. Science 1982, 216:1001-1003.

53. Hess AF: In Collected writings. Volume I. Springfield, IL: Charles C Thomas; 1936:669-719.

54. Hess AF, Unger LJ: The cure of infantile rickets by sunlight. JAMA 1921, 77:39.

55. Holick MF: Sunlight and vitamin D for bone health and prevention of autoimmune disease, cancers, and cardiovascular disease. Am J Clin Nutr 2004, 80(suppl):1678S-1688S.

56. Tejasvi T, Sharma VK, Kaur J: Determination of minimal erythemal dose for narrow band-ultraviolet B radiation in north Indian patients: comparison of visual and Dermaspectrometer ${ }^{\oplus}$ readings. Indian J Dermatol Venereol Leprol 2007, 73:97-99.

57. Holick MF: Sunlight "D"ilemma: risk of skin cancer or bone disease and muscle weakness. Lancet 2001, 357:4-6.

58. Corless D, Gupta SP, Switala S, Barragry JM, Boucher BJ, Cohen RD, Diffey BL: Response of plasma-25-hydroxyvitamin D to ultraviolet irradiation in long-stay geriatric patients. Lancet 1978, 649-651.

59. Toss G, Andersson R, Diffey BL, Fall PA, Larkö O, Larsson L: Oral vitamin D and ultraviolet radiation for the prevention of vitamin $D$ deficiency in the elderly. Acta Med Scand 1982, 212:157-161.

60. Chel VGM, Ooms ME, Popp-Snijders C, Pavel S, Schothorst AA, Meulemans CC, Lips P: Ultraviolet irradiation corrects vitamin D deficiency and suppresses secondary hyperparathyroidism in the elderly. J Bone Min Res 1998, 13:1238-1242.

61. Snell AP, MacLennan WJ, Hamilton JC: Ultra-violet irradiation and 25 hydroxyvitamin D levels in sick old people. Age Ageing 1978, 7:225-228.

62. Chel VGM., Ooms ME, Popp-snijders C, Pavel S, Schothorst AA, Meulemans CCE, Lips P: Ultraiovlet irradiation corrects vitamin D deficiency and suppresses secondary hyperparathyroidism in the elderly. J Bone Mineral Res 1998, 13:1238-1242.

63. Chandra P, Wolfenden LL, Ziegler TR, Tian J, Luo M, Stecenko AA, Chen TC, Holick MF, Tangpricha V: Treatment of vitamin D deficiency with UV light in patients with malabsorption syndromes: a case series. Photodermatol Photoimmunol Photomed 2007, 23:179-185.

64. Scott PM: CLAYTON'S electrotherapy and actinotherapy. 6 edition. London: Bailliere Tindall \& Cassell; 1969.

65. Mussolino ME, Gillum RF: Low bone mineral density and mortality in men and women: The Third National Health and Nutrition Examination Survey Linked Mortality File. Ann Epidemiol 2008, 18:847-850. 
66. Suzuki T, Yoshida H: Low bone mineral density at femoral neck is a predictor of increased mortality in elderly Japanese women. Osteoporosis Int 2010, 21:71-79.

67. Bischoff-Ferrari HA, Willett WC, Wong JB, Giovannucci E, Dietrich T, DawsonHughes B: Fracture prevention with vitamin D supplementation: a metaanalysis of randomized controlled trials. JAMA 2005, 293:2257-2264.

68. Chapuy MC, Arlot ME, Duboeuf F, Brun J, Crouzet B, Arnaud S, Delmas PD, Meunier PJ: Vitamin D3 and calcium to prevent hip fractures in the elderly women. N Engl J Med 1992, 327:1637-1642.

69. Chapuy MC, Arlot ME, Delmas PD, Meunier PJ: Effect of calcium and cholecalciferol treatment for three years on hip fractures in elderly women. BMJ 1994, 308:1081-1082.

70. Lips P, Graafmans WC, Ooms ME, Bezemer PD, Bouter LM: Vitamin D supplementation and fracture incidence in elderly persons: a randomized, placebo-controlled clinical trial. Ann Intern Med 1996, 124:400-406.

71. Nieves J, Cosman F, Herbert J, Shen V, Lindsay R: High prevalence of vitamin $\mathrm{D}$ deficiency and reduced bone mass in multiple sclerosis. Neurology 1994, 44:1687-1692.

72. Plotnikoff GA, Quigley JM: Prevalence of severe hypovitaminosis D in patients with persistent, nonspecific musculoskeletal pain. Mayo Clin Proc 2003, 78:1463-1470.

73. Bischoff-Ferrari HA, Giovannucci E, Willett WC, Dietrich T, Dawson-Hughes B: Estimation of optimal serum concentrations of 25 -hydroxyvitamin $D$ for multiple health outcomes. Am J Clin Nutr 2006, 84:18-28

74. Broe KE, Chen TC, Weinberg J, Bischoff-Ferrari HA, Holick MF, Kiel DP: A higher dose of vitamin $D$ reduces the risk of falls in nursing home residents: a randomized, multiple-dose study. J Am Geriatr Soc 2007, 55:234-239.

75. Graafmans WC, Ooms ME, Hofstee HM, Bezemer PD, Bouter LM, Lips P: Falls in the elderly: a prospective study of risk factors and risk profiles. Am J Epidemiol 1996, 143:1129-1136.

76. Li YC, Kong J, Wei M, Chen ZF, Liu SQ, Cao LP: 1,25-Dihydroxyvitamin D(3) is a negative endocrine regulator of the renin-angiotensin system. $J$ Clin Invest 2002, 110:229-238.

77. Carthy EP, Yamashita W, Hsu A, Ooi BS: 1,25-Dihydroxyvitamin D3 and rat vascular smooth muscle cell growth. Hypertension 1989, 13:954-959.

78. Lee JH, O'Keefe JH, Bell D, Hensrud DD, Holick MF: Vitamin D deficiency an important, common, and easily treable cardiovascular risk factor? J Am Coll Cardio 2008, 52:1949-1956.

79. Michos ED, Melamed ML: Vitamin D and cardiovascular disease risk. Curr Opin Clin Nutr Metab Care 2008, 11:7-12

80. Dustan HP: Obesity and hypertension in blacks. Cardiovasc Drugs Ther 1990, 4(Suppl. 2):395-402.

81. Harris SS, Dawson-Hughes B: Seasonal changes in plasma 25 hydroxyvitamin $\mathrm{D}$ concentrations of young American black and white women. Am J Clin Nutr 1998, 67:1232-1236.

82. Kunes J, Tremblay J, Bellavance F, Hamet P: Influence of environmental temperature on the blood pressure of hypertensive patients in Montreal. Am J Hypertens 1991, 4:422-426.

83. Woodhouse PR, Khaw KT, Plummer M: Seasonal variation of blood pressure and its relationship to ambient temperature in an elderly population. J Hypertens 1993, 11:1267-1274.

84. Krause R, Buhring M, Hopfenmuller W, Holick MF, Sharma AM: Ultraviolet B and blood pressure. Lancet 1998, 352:709-710.

85. Pfeifer M, Begerow B, Minne HW, Nachtigall D, Hansen C: Effects of a short-term vitamin $\mathrm{D}(3)$ and calcium supplementation on blood pressure and parathyroid hormone levels in elderly women. $J$ Clin Endocrinol Metab 2001, 86:1633-1637.

86. Forman JP, Bischoff-Ferrari HA, Willett WC, Stampfer MJ, Curhan GC: Vitamin $D$ intake and risk of incident hypertension results from three large prospective cohort studies. Hypertension 2005, 46:676-682.

87. Martyn CN: The epidemiology of multiple sclerosis. McAlpine's Multiple Sclerosis. 2 edition. WB Matthews ed. Edinburgh London Melbourne and New York: Churchill Livingstone; 1991.

88. Gale CR, Martyn CN: Migrant studies in multiple sclerosis. Prog Neurobiol 1995, 47:425-448.

89. Acheson ED, Bachrach CD, Wright FM: Some comments on the relationship of the distribution of multiple sclerosis to latitude, solar radiation and other variables. Acta Psychiatr Scand 1960, 35:132-147.
90. Norman JE, Kurtzke JF, Beebe GW: Epidemiology of multiple sclerosis in US veterans: 2 . Latitude, climate and the risk of multiple sclerosis. J Chronic Dis 1983, 36:551-559.

91. Goldberg P: Multiple sclerosis: vitamin D and calcium as environmental determinants of prevalence (a viewpoint). Part 1: sunlight, dietary factors and epidemiology. Int J Environ Studies 1974, 6:19-27.

92. Acheson ED, Bachrach CA, Wright FM: Some comments on the relationship of the distribution of multiple sclerosis to latitude, solar radiation, and other variables. Acta Psychiatry Scand 1960, 147(suppl):132-147.

93. Sutherland JM, Tyrer $\mathrm{JH}$, Eadie MJ: The prevalence of multiple sclerosis in Australia. Brain 1962, 85:146-164.

94. Cosman F, Nieves J, Herbert J, Shen V, Lindsay R: High-dose glucocorticoids in multiple sclerosis patients exert direct effects on the kidney and skeleton. J Bone Miner Res 1994, 9:1097-1105.

95. VanAmerongen BM, Dijkstra CD, Lips P, Polman CH: Multiple sclerosis and vitamin D: an update. Eur J Clin Nutr 2004, 58:1095-1109.

96. Cantorna MT: Vitamin D and multiple sclerosis: an update. Nutr Rev 2008, 66(10 Suppl 2):S135-138

97. Raghuwanshi A, Joshi SS, Christakos S: Vitamin D and multiple sclerosis. $J$ Cell Biochem 2008, 105:338-343.

98. Mahon BD, Gordon SA, Cruz J, Cosman F, Cantorna MT: Cytokine profile in patients with multiple sclerosis following vitamin D supplementation. J Neuroimmunol 2003, 134:128-132.

99. Munger KL, Zhang SM, O'Reilly E, Hernan MA, Olek MJ, Willett WC, Ascherio A: Vitamin D intake and incidence of multiple sclerosis. Neurology 2004, 62:60-65.

100. Munger KL, Levin LI, Hollis BW, Howard NS, Ascherio A: Serum 25hydroxyvitamin D levels and risk of multiple sclerosis. JAMA 2006, 296:2832-2838.

101. Aris RM, Merkel PA, Bachrach LK, Borowitz DS, Boyle MP, Elkin SL, Guise TA, Hardin DS, Haworth CS, Holick MF, Joseph PM, O'Brien K, Tullis E, Watts NB, White TB: Consensus statement: guide to bone health and disease in cystic fibrosis. J Clin Endocrinol Metab 2005, 90:1888-1896.

102. Siffledeen J, Fedorak R, Siminoski K, Jen H, Vaudan E, Abraham N, Steinhart H, Greenberg G: Randomized trial of etidronate plus calcium and vitamin D for treatment of low bone mineral density in Crohn's disease. Clin Gastroenterol Hepatol 2005, 3:122-132.

103. Peller S, Stephenson CS: Skin irritation and cancer in the United States Navy. Am J Med Sci 1937, 194:326-333.

104. Garland C, Garland F: Do sunlight and vitamin D reduce the likelihood of colon cancer? Int J Epidemiol 1980, 9:227-231.

105. Gorham E, Garland C, Garland F: Acid haze air pollution and breast and colon cancer in 20 Canadian cities. Can J Public Health 1989, 80:96-100.

106. Garland F, Garland C, Gorham E, Young J Jr: Geographic variation in breast cancer mortality in the United States: a hypothesis involving exposure to solar radiation. Prev Med 1990, 19.614-622.

107. Lefkowitz ES, Garland CF: Sunlight, vitamin D, and ovarian cancer mortality rates in US women. Int J Epidemiol 1994, 23:1133-1136.

108. Schwartz GG, Hulka BS: Is vitamin D deficiency a risk factor for prostate cancer? Anticancer Res 1990, 10:1307-1311

109. Young MR, Ihm J, Lozano Y, Wright MA, Prechel MM: Treating tumorbearing mice with vitamin D3 diminishes tumor-induced myelopoiesis and associated immunosuppression, and reduces tumor metastasis and recurrence. Cancer Immunol Immunother 1995, 41:37-45.

110. Metz RJ, Vellody K, Patel S, Bergstrom R, Meisinger J, Jackson J, Wright MA, Young MR: Vitamin D3 and ceramide reduce the invasion of tumor cells through extracellular matrix components by elevating protein phosphatase-2A. Invasion Metastasis 1996, 16:280-290.

111. Young MR, Halpin J, Hussain R, Lozano Y, Djordjevic A, Devata S, Matthews JP, Wright MA: Inhibition of tumor production of granulocyte-macrophage colony-stimulating factor by 1 alpha, 25-dihydroxyvitamin D3 reduces tumor motility and metastasis. Invasion Metastasis 1993, 13:169-177.

112. Evans SR, Shchepotin El, Young H, Rochon J, Uskokovic M, Shchepotin IB: 1,25-dihydroxyvitamin D3 synthetic analogs inhibit spontaneous metastases in a 1,2-dimethylhydrazine-induced colon carcinogenesis model. Int J Oncol 2000, 16:1249-1254. 
113. Fujioka T, Hasegawa M, Ishikura K, Matsushita Y, Sato M, Tanji S: Inhibition of tumor growth and angiogenesis by vitamin D3 agents in murine renal cell carcinoma. J Urol 1998, 160:247-251.

114. Sundaram S, Sea A, Feldman S, Strawbridge R, Hoopes PJ, Demidenko E, Binderup L, Gewirtz DA: The combination of a potent vitamin D3 analog, EB 1089, with ionizing radiation reduces tumor growth and induces apoptosis of MCF-7 breast tumor xenografts in nude mice. Clin Cancer Res 2003, 9:2350-2356.

115. Lokeshwar BL, Schwartz GG, Selzer MG, Burnstein KL, Zhuang SH, Block NL, Binderup L: Inhibition of prostate cancer metastasis in vivo: a comparison of 1,23-dihydroxyvitamin D (calcitriol) and EB1089. Cancer Epidemiol Biomarkers Prev 1999, 8:241-248.

116. Garland CF, Garland FC, Gorham ED, Lipkin M, Newmark H, Mohr SB, Holick MF: The role of vitamin D in cancer prevention. Am J Public Health 2006, 96:252-261.

117. Bouillon R, Eelen G, Verlinden L, Mathieu C, Carmeliet G, Verstuyf A: Vitamin D and cancer. J Steroid Biochem Mol Biol 2006, 102:156-162.

118. Tuohimaa P: Vitamin D, aging, and cancer. Nutr Rev 2008, 66:S147-152.

119. Ishihara J, Inoue M, Iwasaki M, Sasazuki S, Tsugane S: Dietary calcium, vitamin D, and the risk of colorectal cancer. Am J Clin Nutr 2008, 88:1576-1583.

120. Colston KW: Vitamin D and breast cancer risk. Best Pract Res Clin Endocrinol Metab 2008, 22:587-599.

121. Lappe JM, Travers-Gustafason D, Davies KM, Recker RR, Heaney RP: Vitamin $\mathrm{D}$ and calcium supplementation reduces cancer risk: results of a randomized trial. Am J Clin Nutr 2007, 85:1586-1591.

122. Dembrow M: High vitamin D: Rx for cancer prevention? Clin Advisor 2007, 10:54-57.

123. Khosla S, Melton LJ III: Osteopenia. New Engl J Med 2007, 356:2293-2300.

124. Symmons DP: Epidemiology of rheumatoid arthritis: determinants of onset, persistence and outcome. Best Pract Res Clin Rheumatol 2002, 16:707-722.

125. Adams JS: Extrarenal production and action of active vitamin D metabolites in human lymphoproliferative diseases. In Vitamin D. Edited by: Feldman D. San Diego: Academic Press; 1997:903-921.

126. Merlino L, Curtis J, Mikuls TR, Cerhan JR, Criswell LA, Saag KG: Vitamin D intake is inversely associated with rheumatoid arthritis. Results from the lowa Women's Health Study. Arthr Rheumat 2004, 50:72-77.

127. Leventis $P$, Patel S: Clinical aspects of vitamin $D$ in the management of rheumatoid arthritis. Rheumatology 2008, 47:1617-1621.

128. Cutolo M, Otsa K, Uprus M, Paolino S, Seriolo B: Vitamin D in rheumatoid arthritis. Autoimmn Rev 2007, 7:59-64

129. Cantorna MT, Hayes CE, DeLuca HF: 1,25-dihydroxycholecalciferol inhibits the progression of arthritis in murine models of human arthritis. J Nutr 1998, 128:68-72.

130. Merlino LA, Curtis J, Mikuls TR, Cerhan JR, Criswell LA, Saag KG: Vitamin D intake is inversely associated with rheumatoid arthritis: results from the lowa Women's Health Study. Arthritis Rheum 2004, 50:72-77.

131. Wild S, Roglic G, Green A, Sicree R, King H: Global prevalence of diabetes: Estimates for the year 2000 and projections for 2030. Diabetes Care 2004, 27:1047-1053.

132. Norman AW, Frankel JB, Heldt AM, Grodsky GM: Vitamin D deficiency inhibits pancreatic secretion of insulin. Science 1980, 209:823-825.

133. Bourlon PM, Billaudel B, Faure-Dussert A: Influence of vitamin D3 deficiency and 1,25 dihydroxyvitamin D3 on de novo insulin biosynthesis in the islets of the rat endocrine pancreas. J Endocrinol 1999, 160:87-95.

134. Mohr SB, Garland CF, Gorham ED, Garland FC: The association between ultraviolet $B$ irradiance, vitamin $D$ status and incidence rates of type 1 diabetes in 51 regions worldwide. Diabetologia 2008, 51:1391-1398.

135. Mathieu C, Badenhoop K: Vitamin D and type 1 diabetes mellitus: state of the art. Trends Endocrinol Metab 2005, 16:261-266.

136. Zippitis CS, Akobeng AK: Vitamin D suuplementation in early childhood and risk of type 1 diabetes: a systematic review and meta-analysis. Arch Dis Child 2008, 93:512-517.

137. Peechakara SV, Pittas AG: Vitamin D as a potential modifier of diabetes risk. Nat Clin Pract Engocrinol Metab 2008, 4:182-183.

138. Pittas AG, Dawson-Hughes B, Li T, Van Dam RM, Willett WC, Manson JE, Hu FB: Vitamin D and calcium intake in relation to type 2 diabetes in women. Diabetes Care 2006, 29:650-656.
139. Hypponen E, Laara E, Reunanen A, Jarvelin M-R, Virtanen SM: Intake of vitamin D and risk of type 1 diabetes: a birthcohort study. Lancet 2001, 358:1500-1503.

140. Dye C, Scheele S, Dolin P, Pathania V, Raviglione MC: Global burden of tuberculosis: estimated incidence, prevalence, and mortality by country consensus statement. WHO Global Surveillance and Monitoring Project. JAMA 1999, 282:677-686.

141. Martineau AR, Honecker F, Wilkinson RJ, Griffiths CJ: Vitamin D in the treatment of pulmonary tuberculosis. J Steroid Biochem Mol Biol 2007, 103:793-798

142. Chan TY, Poon P, Pang J, Swaminathan R, Chan CH, Nisar M, Williams CS, Davies PD: A study of calcium and vitamin D metabolism in Chinese patients with pulmonary tuberculosis. J Trop Med Hyg 1994, 97:26-30.

143. Davies PDO, Church HA, Bovornkitti S, Chatumilind A, Byrachandra S: Altered vitamin D homeostasis in tuberculosis. Intern Med (Thailand) 1988, 4:45-47.

144. Strachan DP, Powell KJ, Thaker A, Millard FJ, Maxwell JD: Vegetarian diet as a risk factor for tuberculosis in immigrant south London Asians. Thorax 1995, 50:175-180.

145. Martineau AR, Wilkinson RJ, Wilkinson KA, Newton SM, Kampmann B, Hall BM, Packe GE, Davidson RN, Eldridge SM, Maunsell ZJ, Rainbow SJ, Berry JL, Griffiths CJ: A single dose of vitamin D enhances immunity to Mycobacteria. Am J Respir Crit Care Med 2007, 176:208-213.

146. Ong G: Periodontal reasons for tooth loss in an Asian population. J Clin Periodontol 1996, 23:307-309.

147. Phipps KR, Stevens VJ: Relative contribution of caries and periodontal disease in adult tooth loss for an HMO dental population. J Pub Health Dent 1995, 55:250-252.

148. Stabholz A, Babayof I, Mersel A, Mann J: The reasons for tooth loss in geriatric patients attending two surgical clinics in Jerusalem, Israel. Gerodontology 1997, 14:83-88.

149. Park KS, Nam JH, Choi J: The short vitamin D receptor is associated with increased risk for generalized aggressive periodontitis. J Clin Periodontol 2006, 33:524-528.

150. Krall EA: Osteoporosis and the risk of tooth loss. Clin Calcium 2006, 16:287-290.

151. Ritchie CS, Joshipura K, Hung HC, Douglass CW: Nutrition as a mediator in the relation between oral and systemic disease: associations between specific measures of adult oral health and nutrition outcomes. Crit Rev Oral Biol Med 2002, 13:291-300.

152. Marshall TA, Warren JJ, Hand JS, Xie XJ, Stumbo PJ: Oral health, nutrient intake and dietary quality in the very old. J Am Dent Assoc 2002, 133:1369-1379.

153. Norlen P, Steen B, Birkhed D, Bjorn AL: On the relations between dietary habits, nutrients, and oral health in women at the age of retirement. Acta Odontol Scand 1993, 51:277-284.

154. Krall EA, Wehler C, Garcia RI, Harris SS, Dawson-Hughes B: Calcium and vitamin D supplements reduce tooth loss in the elderly. Am J Med 2001, 111:452-456.

155. Lansowne AT, Provost SC: Vitamin D3 enhances mood in healthy subjects during winter. Psychopharmacology (Berl) 1998, 135:319-323.

156. Brown J, Bianco Jl, McGrath JJ, Eyles DW: 1,25-Dihydroxyvitamin D3 induces nerve growth factor, promotes neurite outgrowth and inhibits mitosis in embryonic rat hippocampal neurons. Neurosci Lett 2003, 343:139-143.

157. Burkert R, McGrath J, Eyles D: Vitamin D receptor expression in the embryonic rat brain. Neurosci Res Commun 2003, 33:63-71.

158. Eyles D, Brown J, Mackay-Sim A, McGrath J, Feron F: Vitamin D3 and brain development. Neuroscience 2003, 118:641-653.

159. McGrath JJ, Feron FP, Burne TH, Mackay-Sim A, Eyles DW: The neurodevelopmental hypothesis of schizophrenia: a review of recent developments. Ann Med 2003, 35:86-93.

160. McCann JC, Ames BN: Is there convincing biological or behavioral evidence linking vitamin D deficiency to brain dysfunction. FASEB J 2008, 22:982-1001.

161. Eyles DW, Smith S, Kinobe R, Hewison M, McGrath JJ: Distribution of the vitamin $D$ receptor and $1 a$-hydroxylase in human brain. $J$ Chem Neuroanat 2005, 29:21-30. 
162. Wang L, Manson JE, Song Y, Sesso HD: Systematic review: Vitamin D and calcium supplementation in prevention of cardiovascular events. Ann Intern Med 2010, 152:315-323.

163. Pittas AG, Chung M, Trikalinos T, Mitri J, Brendel M, Patel K, Lichtenstein AH, Lau J, Balk EM: Systematic review: Vitamin D and cardiometabolic outcomes. Ann Intern Med 2010, 152:307-314.

164. DIPART (Vitamin D Individual Patient Analysis of Randomized Trials) Group: Patient level pooled analysis of 68500 patients from seven major vitamin D fracture trials in US and Europe. BMJ 2010, 340:b5463.

165. Annweiler C, Schott AM, Berrut G, Fantino B, Beauchet O: Vitamin D-related changes in physical performance: a systematic review. J Nutr Health Aging 2009, 13:893-898.

166. Palmer SC, McGregor DO, Craig JC, Elder G, Macaskill P, Strippoli GF: Vitamin D compounds for people with chronic kidney disease not requiring dialysis. Cochrane Database Syst Rev 2009, 4:CD008175.

167. Palmer SC, McGregor DO, Craig JC, Elder G, Macaskill P, Strippoli GF: Vitamin D compounds for people with chronic kidney disease requiring dialysis. Cochrane Database Syst Rev 2009, 4:CD005633.

168. Ferguson $J H$, Chang AB: Vitamin $D$ supplementation for cystic fibrosis. Cochrane Database Syst Rev 2009, 4:CD007298.

169. Bischoff-Ferrari HA, Dawson-Hughes B, Staehelin HB, Orav JE, Stuck AE, Theiler R, Wong JB, Egli A, Kiel DP, Henschkowski J: Fall prevention with supplemental and active forms of vitamin D: a meta-analysis of randomised controlled trials. BMJ 2009, 339:b3692.

170. Witham MD, Nadir MA, Struthers AD: Effect of vitamin D on blood pressure: a systematic review and meta-analysis. J Hypertens 2009, 10:1948-1954

171. Gillespie LD, Robertson MC, Gillespie WJ, Lamb SE, Gates S, Cumming RG, Rowe $\mathrm{BH}$ : Interventions for preventing falls in older people living in the community. Cochrane Database Syst Rev 2009, 2:CD007146.

172. Bischoff-Ferrari HA, Willett WC, Wong JB, Stuck AE, Staehelin HB, Orav EJ, Thoma A, Kiel DP, Henschkowski J: Prevention of nonvertebral fractures with oral vitamin $D$ and dose dependency: a meta-analysis of randomized controlled trials. Arch Intern Med 2009, 169:551-561.

173. Björkman M, Sorva A, Tilvis R: Responses of parathyroid hormone to vitamin D supplementation: a systematic review of clinical trials. Arch Gerontol Geriatr 2009, 48:160-166.

174. Autier P, Gandini S: Vitamin D supplementation and total mortality: a meta-analysis of randomized controlled trials. Arch Intern Med 2007, 167:1730-1737.

175. Jackson C, Gaugris S, Sen SS, Hosking D: The effect of cholecalciferol (vitamin D3) on the risk of fall and fracture: a meta-analysis. QJM 2007, 100:185-192.

176. Bischoff-Ferrari HA, Willett WC, Wong JB, Giovannucci E, Dietrich T, Dawson-Hughes B: Fracture prevention with vitamin D supplementation: a meta-analysis of randomized controlled trials. JAMA 2005, 293:2257-2264.

177. Bischoff-Ferrari HA, Dawson-Hughes B, Willett WC, Staehelin HB, Bazemore MG, Zee RY, Wong JB: Effect of Vitamin D on falls: a metaanalysis. JAMA 2004, 291:1999-2006

178. Cranney A, Tugwell P, Zytaruk N, Robinson V, Weaver B, Adachi J, Wells G, Shea B, Guyatt G, Osteoporosis Methodology Group and The Osteoporosis Research Advisory Group: Meta-analyses of therapies for postmenopausal osteoporosis. IV. Meta-analysis of raloxifene for the prevention and treatment of postmenopausal osteoporosis. Endocr Rev 2002, 23:524-528.

doi:10.1186/1475-2891-9-65

Cite this article as: Zhang and Naughton: Vitamin D in health and disease: Current perspectives. Nutrition Journal 2010 9:65.

\section{Submit your next manuscript to BioMed Central and take full advantage of:}

- Convenient online submission

- Thorough peer review

- No space constraints or color figure charges

- Immediate publication on acceptance

- Inclusion in PubMed, CAS, Scopus and Google Scholar

- Research which is freely available for redistribution

Submit your manuscript at www.biomedcentral.com/submit
Biomed Central 